\title{
"Each Punishment Should Be a Fable": Punitive Analytics, The Punitive-City Diagram, and Punishment as Technology of Power in Foucault's Works of the 1970s and 1980s
}

\author{
MARIO BRUZZONE \\ University of Wisconsin, USA
}

\begin{abstract}
Michel Foucault's Punitive Society lectures make clear that, for him, punishment presents a critical problem. On the one hand, Foucault struggles to develop a conceptual vocabulary adequate to punishment, and particularly to the prison-form as a penal development. On the other hand, the Punitive Society lectures clearly indicate the stakes of punishment. How, Foucault asks, might punishment focalize relations of power? How might it serve as a field of struggle? What does a punitive technology of power look like, if it exists? Indeed, across numerous works from the 1970s and 1980s, Foucault traces the varying place of penalties within penal and punitive tactics, showing how punishment reciprocates historical relations of power and problems of power. Yet it remains necessary to develop Foucault's account of punishment, which is never formalized. In this paper, I develop punishment as a polyvalent technology. Foucauldian punishment may be an analytic, a technology, and-in the allegorical "punitive city" from Discipline and Punish-a diagram of power. I argue that Foucauldian punitive power seizes the body in the name of an authority or a reified power to subordinate individuals to that authority, and with an objective to correct the individual's relation to a multiplicity. It operates "above," at the level of, and in "fragments" of embodied individuals. Further, with Foucault's account of the "punitive city," we find a theoretical model in which punishment becomes the ordering force of the social, and therein a diagram of punitive power exerted in extensive form across the social field.
\end{abstract}

Keywords: diagram, Foucault, punishment, punitive city, punitive power, technology of

\section{INTRODUCTION: THE QUESTIONS OF PUNITIVE POWER}

Nearly three decades ago, the celebrated sociologist David Garland wrote that Michel Foucault's Discipline and Punish "offers not so much a theory of punishment as a mode of 
theorizing about punishment."1 Garland recognized Foucault's method, in which punishment cannot be extricated from the social systems and exterior relations that invest it with power. But Garland found this approach lacking: Foucault, he said, gave no integrated idea of the purpose and use of punishing; no accounting for who is and who should be penalized, for what offenses, by what authority; no thought to the expressive role of punishment; and no reckoning with how penality and punishment fail their objectives. ${ }^{2}$ Foucault's then-available oeuvre was significantly narrower than the wealth of materials present today. Accordingly, some critiques by Garland and his contemporaries hold less weight in light of the passing years. ${ }^{3}$ Even so, Garland's view that in Foucault, "punishment is exclusively a utilitarian means of control" 4 betrays a critical but unacknowledged divergence. For Foucault, punishment emerges as a prism and an "analyser of power relations," 5 as a technology of power, and as a field of struggle. By contrast with Garland, punishment is not a mechanism deployed to "utilitarian" ends, as if it were an object within society, nor a soldier's weapon, but most often a "force exercised on other forces." 6

Foucault used the terms "punishment" and "punitive power" expansively in the periods preceding and following the publication of Discipline and Punish in $1975 .{ }^{7}$ The recent release of his Punitive Society lectures, along with the publication of Foucault's complete Collège de France courses, offers an important opportunity to augment understandings of punishment within and without Foucault's thought. The Punitive Society lectures obviate many of Garland's critiques, particularly those concerning the ends, normativity, and "strategic use" of punishment when it departs from its foundational rationale. However, Foucault introduces a tense and tenuous overlap of punitive and disciplinary technologies in the lectures. At the outset, Foucault makes a series of distinctions, such as a contrast between "the punitive regime of crimes and the disciplinary regime of labor." 8 As the lectures continue, Foucault increasingly

\footnotetext{
${ }^{1}$ David Garland, "Frameworks of Inquiry in the Sociology of Punishment," The British Journal of Sociology 41:1 (1990), 4.

2 David Garland, Punishment and Modern Society: A Study in Social Theory (1990); Garland, "Frameworks of Inquiry."

${ }^{3}$ For example, Garland says that as readers of Discipline \& Punish "we are asked to [simply] accept that the creation of a criminal class became a deliberate feature in a political strategy" in his Punishment and Modern Society, 160. Levelled today, after the publication of the Collège de France lectures and especially The Punitive Society's discussion of the criminal as "social enemy," the same critique would be less worrisome.

4 "Frameworks of Inquiry," 7; italics in original.

${ }^{5}$ Michel Foucault, The Punitive Society: Lectures at the College de France 1972-1973 (2015), 12.

${ }^{6}$ Gilles Deleuze, Foucault (1999), 30.

7 Chronologically, the subsequent works that treat punishment include The Punitive Society; Michel Foucault, "Truth and Juridical Forms" [1973] in Power. Essential Works of Michel Foucault, 1954-1984, Vol. 3, ed. James D. Faubion (2000); Michel Foucault, Psychiatric Power: Lectures at the Collège de France, 1973-74 (2006); Michel Foucault, Abnormal: Lectures at the Collège de France 1974-1975 (2003); Michel Foucault, Discipline E Punish: The Birth of the Prison [1975] (1979); Michel Foucault, The Birth of Biopolitics: Lectures at the Collège de France, 1978-1979 (2008); and Michel Foucault, Wrong-Doing, Truth-Telling: The Function of Avowal in Justice [1981] (2014).

${ }^{8}$ Punitive Society, 72.
} 
superimposes disciplinary forms over forms of punishment, ${ }^{9}$ and by the lectures' conclusion, Foucault twice reads the punitive and the disciplinary together, including the remark-from Foucault's notes, rather than the spoken transcript-regarding "the analysis of a form of power I have called punitive, which it would be better to call disciplinary."10 Yet Foucault does not stick with a progressive account, instead returning to implicit distinctions between the punitive and the disciplinary, between punishment and discipline, in subsequent works. Simultaneously, the Punitive Society lectures establish that the exchange between punishment and penality is contingent and unstable. For Foucault, punitive power represents a coercive correction that operates as a social force rather than power crystallized in institutional form. Penality operates orthogonally to punishment, as a system of mandated penalties and sanctions but which is neither exhausted by nor exhausts the punitive. The punitive-penal distinction opens questions, both historical and abstract, of their coincidence as relays of power.

The Punitive Society lectures also help to make sense of Discipline and Punish's peculiar claim that sovereignty, disciplinarity, and the "punitive city" present "three technologies of power" by which the social may be organized. ${ }^{11}$ While sovereignty and discipline are broadly familiar, the less familiar "punitive-city" conceit is Foucault's abstraction of $18^{\text {th }}$ century proposals to maintain social order through public punishment. In the punitive city, public and publicized penalties - "at the crossroads, in the gardens, at the side of roads being repaired or bridges built"12 - correct offenders and keep the potentially unruly in line; they send messages about what and who are to be punished; and they remind subjects of the political order in which they live. As a technology of power, sovereignty coerces obedience to the sovereign will via "nonisotopic" series of hierarchical relations, for example from king to seigneur to vassal and peasant. ${ }^{13}$ Disciplinary power creates docile subjects by habituating bodies and their forces in institutions. Analogously, the punitive city uses public punishments to guarantee a social order by exploiting representations, such that power passes across multiplicities, individuals, and individuals' "somatic fragments." 14 However, the "punitive city" is but one use of punishment - and a technology that never took root to the extent of sovereignty and disciplinarity.

From the point of departure of technologies of power, this paper offers a minimal account of punishment and punitive power. I argue that Foucauldian punitive power operates when authority seizes the body; the imposed penalty targets the relations between the individual and the multiplicity, as well as "somatic fragments" and the individual; and the act of punishment imbues a causal story that differentiates the

\footnotetext{
${ }^{9}$ For example, in the historical filiation of the prison through lettres de cachet in Punitive Society, 139-40; and in the worker's livret or work-log in Punitive Society, 193-194.

10 Punitive Society, 237n.

${ }^{11}$ Foucault, Discipline $\mathcal{E}$ Punish, 130.

${ }^{12}$ Discipline $\mathcal{E}$ Punish, 113.

13 On this reading of sovereignty, see Foucault, Psychiatric Power, 42-45; and Michel Foucault, Security, Territory, Population: Lectures at the Collège de France 1977-78 (2009), 11-12 and 65.

14 Psychiatric Power, 44.
} 
offender and any associated collectivities. The following section rehearses Foucault's archaeology of punishment, dwelling on the punitive theories of criminology's "great reformers" that resonate with contemporary problems of penality and state punishment. The third section considers Foucault's analysis of punishment as an operation "above," at the level of, and in "fragments" of embodied individuals. Consequently, punishment presents a field of struggle or fields of struggle. The fourth section turns to the "punitive city," which I read both as a theoretical culmination of the $18^{\text {th }}$ century penal reformers' project, as well as a diagram of coercive deterrence. Here I depart from Foucault, and argue that his dichotomous choice of "punitive city or coercive institution" was misconceived because the functions of one may be used inside or alongside the other. By way of conclusion, I offer a speculation on the relations of disciplinary and punitive power in which the two might operate in conjunction rather than convergently or complementarily.

My principal reading method in this paper is to "read Foucault with Foucault," privileging points of convergence across Foucault's various treatments of punishment and punitive power. Contemporary encounters with Foucault's thought must span a variety of materials and genres, including books, lecture series, one-off talks, academic interviews, journalistic interviews, and editorials. Foucauldian scholarship offers various interpretivist strategies, ${ }^{15}$ including periodization accounts of the "archaeological phase," "genealogical phase," and "ethical turn"; periodization by published work, where lectures such as The Punitive Society and Abnormal prefigure texts such as Discipline and Punish and History of Sexuality, Volume 1, respectively; and fledging Foucault's materials as projects independent from his published books and essays, with each text the momentary capture of a slowly morphing set of projects and intellectual interests. In this paper, I fall into the last of these, looking to the ways that one text might inform another while allowing that the texts may contain contradictions both internally and in juxtaposition with one another.

\section{NOTES TOWARD A PUNITIVE ARCHAEOLOGY}

By beginning his analyses of punishment with classical antiquity, Foucault immediately troubles any congruence between punishment and institutional or state penality. In the eras prior to the emergence of the state, ${ }^{16}$ violators of the social order might well be "punished"17; but these punishments were quite dissimilar to the punishments that would emerge in sovereign penality. In Foucault's examples of the classical Greek system, the medieval German system, and pre-capitalist feudalism, punishment

\footnotetext{
${ }^{15}$ Hubert L. Dreyfus and Paul Rabinow, Michel Foucault: Beyond Structuralism and Hermeneutics (1983); Eric Paras, Foucault 2.0: Beyond Power and Knowledge (2006); Henry Martyn Lloyd, "Power, Resistance, and the Foucauldian Technologies" Philosophy Today 56:1 (2012), 26-38; Patrick Gamez, "Did Foucault Do Ethics? The 'Ethical Turn,' Neoliberalism, and the Problem of Truth" Journal of French and Francophone Philosophy Revue de la philosophie française et de langue française XXVI:1 (2018), 107-133.

${ }^{16}$ Foucault dates this to the end of the sixteenth century in Security, Territory, Population, 165.

17 "Truth and Juridical Forms," 18.
} 
responds to interruptions of the social order. All three repaired violations of the social order by appeals to force: the prevailing party in a dispute would be the party who could call upon greater violence, physical strength, glory, or status. ${ }^{18}$ In the juridical apparatus of classical Greece, as Foucault describes it, claims presented in legal testimony were mediated by the speaker's social status-claims which might concern events in question or the claimants' authority. The magistrate or judge recorded the proceedings, arbitrated the status of the litigants, and made points of order. Foucault's interest lies in juridical procedure as part of a project to historicize truth and the production of truth: how Greeks determined who is legally right and what penalties apply for the one who is legally wrong. ${ }^{19}$ In a context where the "demonstration of truth becomes a political task," 20 the court acted as arbitrator of a social order that was never completely static and enrolled the penalty as a consequence for a legal wrong.

Medieval German society settled disputes more actively, through an ongoing and private "war between individuals" where each violation that one suffered could be rectified by retribution on the party that caused it. The Germanic judicial apparatus intervened not to mandate a return to order, but to offer a venue for either a "regulated way of making war" or a brokered settlement. ${ }^{21}$ Penalties were payments, but also methods of equilibrating the balances of social forces. In this sense, the court served as both the scene of and the field for struggles over the social order. The court has a similar place in Foucault's exposition of feudal dispute resolution, centered around the test: "the test did not serve to name, to identify the one who had told the truth; rather, it established that the stronger individual was, at the same time, the one who was right."22 The feudal test - from verbal formulas for oaths, to physical tests, to physical combats did not establish the right social order so much as it allowed that order to be manifested. Where punishment appeared, it appeared in the form of the stronger party wishing to level its force on the weaker, rather than from the institutions of adjudication.

European monarchies reconfigured the place of jurisprudence and punishment as they accumulated and centralized the means of force, beginning in the twelfth century and then again during the late medieval period. Institutional punishment arose here, with an epistemic shift. The monarchy took on the role of creating and maintaining order, no longer content to be the most powerful force among forces. This shift entailed that offenses created both concrete victims who had been cheated, robbed, assaulted and so on, as well as an abstract victim: the sovereign who was "injured by the mere fact that

\footnotetext{
${ }_{18}$ While all used institutional or sovereign punishment at times, it was not a major strategy; regarding Greek punishment, see Punitive Society, 10; regarding medieval German punishment, see "Truth and Juridical Forms," 35; finally, Foucault gives several examples of punishment under feudalism, such as during the Nu-pieds rebellion, in the notes to his 1 December 1971 lecture of Théories et institutions pénales: Cours au Collège de France (1971-1972) (2015).

19 See the April 22, 1981 lecture in Wrong-Doing, Truth-Telling.

${ }^{20}$ This phrasing comes from Michel Foucault, Lectures on the Will to Know: Lectures at the Collège de France (1970-1971) (2009), 183.

21 "Truth and Juridical Forms," 34ff.

22 "Truth and Juridical Forms," 39.
} 
an offense or a crime had occurred" within "his" purview. ${ }^{23}$ If the sovereign could be injured by violations of "his" order, then "his" response would necessitate the full right of "his" power: the sovereign righteousness to punish, the sovereign privilege to do violence, and the sovereign interest in its control over the social multiplicity. The famous execution of Robert-François Damiens, with which Foucault opens Discipline and Punish, epitomizes the sovereign restoration. It was not enough simply to imprison nor to execute Damiens, who had attacked the king with a penknife and presented little real, political threat. Rather, in a demonstration of the full power of Louis $\mathrm{XV}$, Damiens was tortured, pierced with red-hot pokers, drawn and quartered, and finally burned at the stake. Foucault emphasizes across works that the sovereign responds to violations of "his" authority by pitting "his" power against the individual's and demonstrating the excess of violence that the sovereign wields over the individual. ${ }^{24}$ What Foucault terms the "penal ensemble" - which is to say, penality - originates in this "practice of justice organized by reference to the exercise of sovereign political power." 25

However, monarchical penality was practically constrained by the friction of multiplied relays. The growth of the administrative and tax-collection apparatus by the French monarchy-Foucault's major example-extended its legal reach and extractivist capacities but also legitimated nobiliary privilege in the regional parlements. ${ }^{26}$ Most sentences were mandated by the king's laws but adjudicated and carried out by a local elite emplaced in a way that the king and king's agents were not. At times there was deep judiciary resistance to carrying out mandated sanctions, including the refusal by individual judges to enforce laws and whole parlements to register certain edicts. ${ }^{27}$ The non-elite classes also engaged in popular refusals of unjust laws and sentences - at times without disputing any underlying truth to the charge - to force a sort of negotiation with the juridical authority or appropriate juridical power through spontaneous sedition. ${ }^{28}$ The abstract victim had aggravated sovereign power's vulnerability and multiplied the sites where it might be resisted. If the sovereign could be harmed in the market plaza and in the storeroom in addition to the field of battle-through petty theft and tax evasion, and beyond interpersonal violence - then the means for subverting and diverting the sovereign will were multiplied to an equal extent. Thus, if Frédéric Gros is correct that in this period "social equilibrium depends on alliances and tacit agreements between certain classes to bypass laws," 29 then such "illegalisms" present a constant counterforce to monarchical use of sovereign power.

\footnotetext{
${ }_{23}$ "Truth and Juridical Forms," 42.

${ }^{24}$ e.g. Foucault, Abnormal, 82ff.; Discipline \& Punish, 47ff.; Punitive Society, 33-34.

${ }^{25}$ Punitive Society, 111.

${ }^{26}$ This point appears in consolidated form in the notes for the $1^{\text {st }}$ of December 1971 lecture of Théories et institutions pénales; additionally, Foucault's extended treatment of Boulainvilliers in "Society Must Be Defended": Lectures at the Collège de France, 1975-76 (2003) hinges on the nobiliary struggle for their place in the late French monarchy's distribution of the relays of sovereign power.

${ }^{27} 24$ November 1971 lecture notes, Théories et institutions pénales.

${ }^{28}$ Discipline E Punish, 59ff.; 21 February 1973 and 28 February 1973 lectures, Punitive Society.

${ }^{29}$ Frédéric Gros, "Is There a Biopolitical Subject? Foucault and the Birth of Biopolitics," in Biopower: Foucault and Beyond, ed. Vernon Cisney and Nicolae Morar, trans. Samantha Bankston (2016), 262.
} 
In the late 1700s a juridical movement emerged in opposition to the instabilities and unreliability of absolute sovereign power. The "'great reformers" of the movementBeccaria, Brissot, Servin, and others to whom Foucault returns across his works - took sovereignty's "bad economy of power" as their problem. ${ }^{30}$ Their historical moment was marked by four features. First, violations of the social order were shifting toward property crimes and away from regulatory and violent crimes, largely with the growth in capitalist relations. Second, prior to the emergence of the reformers, the law had increasingly indicated for severe sanctions for minor offenses, which, third, had been applied with increasing irregularity. Fourth, the reformers largely believed crime to be increasing-despite, Foucault tells us, contemporary empirical evidence to the contrary. ${ }^{31}$ The social order, the reformers reasoned, was breaking down, and in their proposals they responded with a series of substitutions and exchanges. Two are especially pertinent to this article. The first exchanged abstract victims of crime. Where the abstract victim had been the sovereign, with the reformers it is "society." In their theory, criminal violations present an "attack" on a society that all subjects are invested in, and penality is society's "counter-war." ${ }^{22}$ With "society" as the abstract victim of the offense, the reformers' beliefs about what made good laws led them to formulate deterrence, rather than sovereign revenge, as the moral basis for punishment. ${ }^{33}$ Deterrence appears because society can only be injured in its interests but retains a righteous power to defend those interests and the juridical and penal systems are granted privilege to do so.

The second exchange made punishment (or its threat) the basis for social order. The reversal of the "temporal direction of punishment," 34 from restoring a past state to protecting a current state of order from future disobedience, also inverted the analytic priority of order and punishment. The reformers proposed a series of public punishments that were to act as "semio-techniques," 35 as public lessons, linking crime and punishment for observers. If every crime is a wrong against both its concrete victim but also, abstractly, a wrong against all, then in the production of the criminal as "social enemy" 36 everyday subjects should hear an implicit appeal to identify with authority. Sedition would decline. By substituting abstract victims, the reformers naturalized the prevailing political authorities and the prevailing social order as a proper arrangement of "society." As each punishment would "teach a lesson," 37 punitive power would ground the social order. The reformers thus solidified a rising bourgeois ideal of social order against both monarchical power and lower-class illegalisms, substituted an ideal

\footnotetext{
30 Discipline E Punish, 79.

${ }^{31}$ Discipline $\mathcal{E}$ Punish, 75-79.

32 Punitive Society, 33.

33 "Truth and Juridical Forms," 53-54.

${ }^{34}$ Discipline E Punish, 126.

${ }^{35}$ Discipline $\mathcal{E}$ Punish, 94; 103; 255.

36 Punitive Society, 44. More generally, see the 10 January 1973, 17 January 1973, and 24 January 1973 lectures.

${ }^{37}$ Discipline $\mathcal{E}$ Punish, 113.
} 
of consistency for that of justice, and legitimated a "power to punish...distributed in homogeneous circuits capable of operating everywhere, in a continuous way, down to the finest grain of the social body." 38

Foucault describes the reformers' historical moment, the point of inflection between sovereignty and disciplinarity, with a question: "punitive city or coercive institution?" 39 The question concerns either state control and public punishment, or dispersed coercive correction and private punishment. Yet the reformers failed to foresee that social control would move outside the juridical system, and then outside the formal state. They had thought of punishment as within the ambit of state power, rather than a form of power with polyvalent application and dissociable from penality. ${ }^{40}$ Punishment leapt outside of the formal state to all sort of other institutions, some tenuously connected to political power-such as schools and asylums - and others outside the formal state yet sustained by exchanges of state power-such as factories and hospitals. The leap undermined their project. ${ }^{41}$ Disciplinary institutions multiplied. Under the "whole network of nonjudicial power" within disciplinary institutions, punishment became invested in procedures to condition subjects' habitual obedience, evaluated on visible behaviors "at the level of the behavioral potentialities they represented." 42 In other words, disciplinary power came to reproduce itself through norms derived through institutional observation and enforced by punishments. ${ }^{43}$

Foucault's analysis contains several suggestions for an analysis of punishment. First, punishment appears as an object of contestation but also, when actualized, to be allied with authority rather than working against it. Greek, German, feudal, and monarchical punishments all occur on behalf of authority and not against authority. Second, popular punishments recapture authority to deploy it on behalf of another group. The reformers' project to ally "society" against offenders worked against the power of the sovereign but without dissolving the authority to punish. Third, conceptions of punishment and punitive power are reciprocal. The reformers' ideal of the "punitive city" and the disciplinary institution serve as models and as concrete practices through which power can be actualized. Discipline multiplies institutions of government and privatizes them in "establishments [that] take the State structure as their model: they are all little States that are made to function inside the State." 44 While the coercive institution-the disciplinary institution - comes to a place of prominence in Foucault's historical account, it does not exhaust either power or punishment. The next two sections consider, first, the operations of punitive power and, second, how the supervention of the coercive institution may not render the punitive city outmoded.

\footnotetext{
${ }^{38}$ Discipline E Punish, 80.

39 Discipline E Punish, 129.

40 "Truth and Juridical Forms," 82-83.

${ }^{41}$ Punitive Society, 209; "Truth and Juridical Forms," 79; Discipline E Punish, $211 \mathrm{ff}$.

42 "Truth and Juridical Forms," 57.

${ }_{43}$ "Truth and Juridical Forms," 79; Punitive Society, 213-215.

${ }^{44}$ Punitive Society, 209.
} 


\section{WHAT IS IT TO PUNISH? THE ELEMENTS OF PUNISHMENT}

Foucault's engagements with punishment occur alongside a rising priority of genealogy in his thought and method. By contrast with Foucault's archaeological approach to track the discursive bounds and thereby conceptual possibilities within a place and time, his genealogical method locates the force relations by which discourses, institutional forms, procedures, and technologies of power come into being and are stabilized. In many ways, Foucault's work on punishment formalizes and refines Nietzsche's unsystematic provocations on its uses and force-relations, to produce, in Garland's words, "a kind of penological rendering of Nietzsche's Genealogy of Morals." 45 For Nietzsche "the concept 'punishment' presents...not just one meaning but a whole synthesis of 'meanings'" 46 that defy any attempt at unity. Punishment takes many of the tactical forms that Foucault studies-the repayment of debt, the punishment as settlement to end cycles of vengeance, the punishment as war against "an enemy of peace, law, order, [and] authority" 47 - while it remains "absolutely undefinable." 48 For Foucault, by contrast, "the concept "punishment" is too limited an approach. "Punishment" denotes a state of affairs and is thereby descriptive, but punishment is also a strategic field of - but not limited to-discourse and discourse's perlocutionary effects, as well as a technology of power through which an order is created, retained, repaired, or extended in new form. The problem of punishment lies not in its meanings but its operations as a strategic field and the strategic use of penal institutions.

A persistent critique of Foucault from criminology and the sociology of punishment has held that Foucault "presents the utopian ideals of the $18^{\text {th }}$-century reformers...as though they were actual reforms of the $18^{\text {th }}$ and $19^{\text {th }}$ centuries." 49 Yet the Punitive Society lectures make clear that Foucault's interest as a "genealogist" lies in the disjuncture between proposal and adaptation, indeed how the prison-form can only be derived with a moralized notion of religious repentance. ${ }^{50}$ His impelling question is the strategic use afforded by a penal institution. A minimal problematic of punishment remains necessary to such an account. This section draws out the points of convergence in Foucault's accounts of punishment to analyze punitive power's operations and capacities. I argue that, for Foucault, punishment describes authority's corporeal appropriation of an offender, a narration that the offense is the cause of the punishment, and a leveraging of that causal story to subordinate. I close by considering Foucault's distinction between the punitive, which concerns the operations of punishment, and the penal, which concerns sanctioning. The critical point is that punishment need not be

\footnotetext{
45 Punishment and Modern Society, 168.

${ }^{46}$ Friedrich Nietzsche, On the Genealogy of Morality [1887] (2006), 53.

${ }^{47}$ Nietzsche, On the Genealogy of Morality, 54.

48 On the Genealogy of Morality, 53.

${ }^{49}$ C. Fred Alford, "What Would It Matter If Everything Foucault Said about Prison Were Wrong?," Theory and Society 29:1, 134. Near-identical critiques are found in, e.g., Punishment and Modern Society; and Loïc Wacquant, Punishing the Poor: The Neoliberal Government of Social Insecurity (2009).

5021 February 1973 lecture, Punitive Society; Bernard E. Harcourt, “The '73 Graft: Punishment, Political Economy, and the Genealogy of Morals" (2015).
} 
carried out through state or carceral means - indeed, to think punishment only through a modern state evacuates historically contingent formations of punitive power that Foucault sought to analyze.

Punishment is neither a trans-historical category nor a process necessary to the social, but rather a series of relations partially and temporarily unified by its exterior. Following Paul Patton's observation that Foucault operates through an Aristotelian armature of multiple levels of causal explanation,,51 there is no ultimate "source" of punishment but rather a set of conditions necessary to punishing. First, authority ${ }^{52}$ serves as the "crucial emergent field" 53 for any sort of punishing to arise. Those who punish include family patriarchs ${ }^{54}$; the heads or "spiritual directors" of Benedictine monasteries 55 ; factory owners and foremen ${ }^{56}$; doctors ${ }^{57}$; King Louis XV and his agents ${ }^{58}$; "society," in the reformers' ideal organization"59; and distributed actors who appropriate statistical methods of biopolitical regimes to set desired norms that differ from observed norms. ${ }^{60}$ All are invested with authority, yet few are state agents. Authority is wielded over subjects through punishment across both practical and theoretical distinctions internal to forms of power, such as public-private and state-society. Conversely, the subject of punishment is "the correlate of [a] governmental power" 61 yet which is not state authority. Foucauldian punishment requires a subject attached to authority whom authority attempts to correct. Consequently, punishment constitutes a binding of the subject to power in a form where that power is constituted through sociality. If such a power is the state under disciplinary and sovereign governance in recent centuries, then it is not that punishment requires a state but instead that the state is the dominant structure of the authority-individual relation in the context of the analysis.

Second, punishment refers to an operation of power that invariably involves power seizing a subject's body, ${ }^{62}$ to differing intensities. Foucault makes this point early in Discipline and Punish:

\footnotetext{
${ }^{51}$ Paul Patton, "Power and Biopower in Foucault," in Biopower: Foucault and Beyond, ed. Vernon Cisney and Nicolae Morar (2016), 102-117.

52 "Authority" is Foucault's own term in Punitive Society, 208.

${ }^{53}$ Bob Jessop, "From Micro-Powers to Governmentality: Foucault's Work on Statehood, State Formation, Statecraft, and State Power," Political Geography 27 (2006), 34-40.

${ }^{54}$ Psychiatric Power, 80; see also Chloë Taylor, "Foucault and Familial Power," Hypatia 27: 1 (2012), 201-218.

${ }^{55}$ Wrong-Doing, Truth-Telling, $172 \mathrm{ff}$.

56 "Truth and Juridical Forms," 83.

${ }^{57}$ Psychiatric Power, 10-12.

${ }^{58}$ Discipline $\mathcal{E}$ Punish.

${ }^{59}$ Punitive Society, 72.

${ }^{60}$ Foucault, Birth of Biopolitics; see also Gilles Chantraine, "The Post-Disciplinary Prison," in Discipline, Security, and beyond: Rethinking Foucault's 1978 \& 1979 College de France Lectures, ed. Bernard E. Harcourt (2008), 55-76.

${ }^{61}$ David Newheiser, "Foucault, Gary Becker and the Critique of Neoliberalism," Theory, Culture \& Society 33:5 (2016), 13.

${ }^{62}$ See the discussion on the body in Foucault in Dreyfus and Rabinow, Michel Foucault: Beyond Structuralism and Hermeneutics, 110-115.
} 
But we can surely accept the general proposition that, in our societies, the systems of punishment are to be situated in a certain 'political economy' of the body: even if they do not make use of violent or bloody punishment, even when they use 'lenient' methods involving confinement or correction, it is always the body that is at issuethe body and its forces, their utility and their docility, their distribution and their submission. ${ }^{63}$

He offers at least two registers in which power seizes the body. At one level lie the material forces of punishment. Foucault's Punitive Society discussion offers exclusion, redemption, marking, and imprisonment as the "major forms of punitive tactics." 64 To exile or deport is to cast out the body, to deprive it of its means of survival and sustenance. Redemption burdens the body with obligations; it often coerces labor and other forms of physical compliance, either as condition of the sanction or as the mechanism by which amends can be made. Marking, scarification, amputations and branding all seize the body of the criminal to alter its physical form. Imprisonment is the body's forcible or obligatory sequestration. At another level, punitive power would always seem to invest a "political economy" in the body that exceeds the individual as well as the offender-authority dyad. The operations of disciplinary institutions require that the body be passed over to power such that the subject can be reconstituted or differently constituted. So too the supplice or torture, famously exemplified in Damiens, concerns the economy of power made manifest in suffering. The point here is that a penalty and a punishment may be leveled on a body, yet the body does not act as a limit for punishment's spatial operations. Rather, punishment leverages the body's triple character as the surface of inscription on which representations can be "read," as the target which must be made to conform to a multiplicity in its actions, and as the material through which intensities of experience are lived..$^{65}$

Third, methods of subordination through punishment are not uniform across modalities of power, nor historically. A major implicit contrast concerns the subject of punishment, the subject under punishment, and the offender's relation to a multiplicity. For the pastoral power of the early monastics, punishment served as restorative practice-"penance was a medicine"66 - while simultaneously returning the subject to the pious multiplicity that could only achieve salvation together. Where the sovereign power descends to punish - to lay claim to, to manifest its power on-it does so devolving power to judges, intendants, executioners, and so forth, claiming power in the symbols of divine right and in the figure of the sovereign person. Foucault claims that, although it did individuate bodies of offenders at strategic moments,

\footnotetext{
${ }^{63}$ Discipline E Punish, 25.

${ }^{64}$ Punitive Society, 6-8; 67ff.

${ }^{65}$ Foucault's reading of the body in Nietzschean genealogy corroborates my more limited point concerning punishment. See Michel Foucault, "Nietzsche, Genealogy, History" [1971] in Aesthetics, Method, and Epistemology. Essential Works of Michel Foucault, 1954-84, Vol. 2 (1998), 369-391.

${ }^{66}$ Wrong-Doing, Truth-Telling, 183.
} 
you can see that the relationship of sovereignty is a relationship in which the subject element is not so much, and we can even say it is almost never, an individual, an individual body. The relationship of sovereignty applies not to a somatic singularity but to multiplicities - like families, users - which in a way are situated above physical individuality, or, on the contrary, it applies to fragments or aspects of individuality, of somatic singularity. ${ }^{67}$

Individual punishment serves to order multiplicities, which are the "subject-function" in the political technology of sovereignty. Punishment passes from the one to the multiplicity. By contrast, punishment under discipline marks out not the collective but the individual-qua-subject. Disciplinarity tends to refuse multiplicities as sites of intervention, because its "subject-function is fitted exactly on the somatic singularity: the subject-function of disciplinary power is applied and brought to bear on the body, on its actions, place, movements, strength, the moments of its life, and its discourses, on all of this." 68 Punishment performs a joining function in discipline, coercing conformity to a norm.

Analogizing to Foucault's analysis of the concrete and abstract victims of criminal offenses may be generative to understanding the join. Consider punishment's abstract target. In the economies of power of sovereignty, the penal reformers, and the pastoral monastics, the offense separates the wayward offender from the multiplicity. Punishment restores the social order or state of grace through reincorporation. Under discipline (and, it would appear, biopower) the norm is the join by which the subject's relation to a collectivity is understood and corrected. The individual is given, and separate; punishment integrates him or her. However, punishment requires another integration, in which the elements "below" the individual are incorporated into a subject or subjects. Recalling Damiens a final time, the geography of power with which the King's agents could punish him was limited, on the one hand, "below" Damiens to the aspects of felt experience that could make him suffer, the intensities of pain he could be made to feel, but also the sympathetic experience of those who might observe the torture; and on the other, "above," to coding Damiens as part of a collective subject of "the people" and in opposition to the sovereign. The abstract target was the relation of Damien's body, its forces, and his affects to Damiens-as-subject; and Damiens-as-subject to the multiplicity to which he was ascribed. Likewise, if Foucault's statement that "the other side of the disciplinary relationship is punishment" 69 would introduce a problem, we might dissolve it by recognizing that the power to punish allows modalities of power to pass across bodies' "fragmentary" pre- or non-individuated forms to singular individuals. To the extent that punitive pressure functions as the inverse or reciprocal form of discipline, disciplinarity uses punishment to shape a subject who will maintain the social order all on his or her own.

\footnotetext{
${ }^{67}$ Psychiatric Power, 44

68 Ibid., 55.

${ }^{69}$ Ibid., 51.
} 
Fourth, punishment offers a narrative - a story about reasons for the penalty, if not a justification - both to the present and retrojected into the past. The "semio-technique" of punishment creates a motivated semiotic relation between the offender and a cause, ${ }^{70}$ one easily blurred into political technique of punishment that presumes the rightfulness of rectifying violations of the social order. For example, Foucault says:

when a so-called exemplary punishment was imposed on an action, even and above all when the action was apparently of little importance or consequence, it was in fact precisely with the aim of having a corrective effect, if not on the culprit himselfbecause he was hardly corrected if he was hung. On the other hand, the correction, the corrective effect was clearly addressed to the rest of the population. To that extent, the practice of public torture and execution as an example was a corrective and disciplinary technique. ${ }^{71}$

Foucault's discussion uses sovereign punishment, which in its reconstitution of sovereign authority embeds an offense-response story. No "corrective" is available without such a link between behavior and penalty. Moreover, some collectivity must accept the offense-response story as meaningful, although parts of that story can be veiled. If a disciplinary function is to operate within sovereign power, the audience must juxtapose itself against the penalized offender but also, in the individuals who comprise the audience, identify with the offender, that is, self-identify as penalizable.

While sovereignty directs this causal story to a subordinated "population, "with discipline the causal story is duplicated. Within disciplinary institutions, behaviors create records, records invoke diagnoses, and diagnoses implicate treatments as the basis for correcting "mis"behaviors. Mitchell Dean writes that in the period when the disciplines came to prominence, "The object of the whole penal ritual... is not only the crime but also the circumstances, instincts, passions, desires, effects of environment or heredity, of the criminal manifest in the crime."72 Something in the offender's conduct or being-milieu, character, or upbringing, but also behaviors, opinions, membership or identity - had led to the scene of punishment. Discipline uses written records to discover these "instincts, passions, desires...manifest in the crime." On the one hand, discipline imitates sovereignty to make an audience of the collected subjects whose comportment and habits are to be trained. On the other hand, the records make an audience of the diagnostician, who elects proper courses of treatment. "Mis" behaviors should not imply agency or causal responsibility, although they tend to blur: in Foucault's example of the prison, the advance that enables imprisonment to supersede other penal tactics is the insertion of moral desserts ${ }^{73}$ via notions of wrongdoing for which an offender may not

\footnotetext{
70 Discipline E Punish, 94ff.; Gary Genosko, "Special Semiotic Characters: What Is an Obstacle-Sign?" MediaTropes IV:1 (2013), 101-111.

71 Security, Territory, Population, 6-7. Here I have preferred Foucault's audio text, given in a footnote on page 6 , to the editors' amended text, which I find less clear.

72 Mitchell Dean, Critical and Effective Histories: Foucault's Methods and Historical Sociology (2002), 161.

${ }^{73}$ See 7 February 1973 lecture, Punitive Society.
} 
be morally responsible yet for which the offender is the final cause and thereby punishable. ${ }^{74}$

I close this section by returning to Foucault's criminological interlocutors. If punitive and penal phenomena such as the prison correlate only contingently, following Foucault through the punitive-penal distinction may help to clear up lingering confusion in commentators such as Loïc Wacquant. I use Wacquant here because his work exemplifies a pair of prevailing assumptions about Foucault's work on punishment. For Wacquant:

While its originary medium resides in the application of legal coercion to enforce the core strictures of the sociomoral order, punishment must be viewed not through the narrow and technical prism of repression but by recourse to the notion of production. The assertive rolling out of the penal state has indeed engendered new categories and discourses, novel administrative bodies and government policies, fresh social types and associated forms of knowledge across the criminal and social welfare domains. ${ }^{75}$

While Wacquant has critiqued Foucault-more on that below-here I want to situate the impasse between Wacquant and Foucault at, first, the level of the penal-punitive distinction. Wacquant consistently conflates the punitive and the penal, which the subtle switch in the first and second sentences above exemplifies. Certainly the "penal state" has effected many changes along the lines that Wacquant asserts. But contemporary carceral power is only one instance of penal power. In the Foucauldian idiom, the penal concerns sanctioning-who gets sanctioned, for what, via what mechanisms, and through what channels - and punitive concerns punishment-how offense and penalty are linked, what penalties may do when employed, and the system of punishment in which a penalty is grounded.

A penal-punitive distinction destabilizes the presumption of continuity between a sanction and the punishment that it mandates, but even further, enables an analysis of how punishment operates apart from and in excess of the legal domain. In the Punitive Society lectures, Foucault claims that in the unified "tactic" of discipline at the moment of its consolidation

We have therefore two ensembles: The penal ensemble, characterized by the prohibition and the sanction, the law; and the punitive ensemble, characterized by the coercive penitentiary system. The first ensemble brings with it a certain theory of the infraction as an act of hostility towards society; the second brings with it the practice of confinement. ${ }^{76}$

Both punishment and penality have their most intense effects outside of court, on subjects who are never accused, who may never be prosecutable despite legally noncompliant conduct. However, punishment has no necessary relation to Wacquant's

\footnotetext{
${ }^{74}$ I thank an anonymous reviewer's comments for the argument in this paragraph.

75 Wacquant, "Bourdieu, Foucault, and the Penal State in the Neoliberal Era," in Foucault and Neoliberalism, eds. Daniel Zamora and Michael Behrent (2016), 121; see also Wacquant, Punishing the Poor, 295.

76 Punitive Society, 111.
} 
"application of legal coercion." For Foucault, relations of force within society determine but never permanently settle the boundaries that distinguish the illegal and the offense from injurious behaviors that fail to merit punishing and from tolerated noncompliant behaviors. ${ }^{77}$ The penal operates both "inside" the law and in the distribution of "illegalisms," just as the punitive does. Yet one cannot analyze punishment by analyzing the penal sanction. Instead, the punitive and the penal might be understood as mutually inscribed functions, one for creating difference and another for selecting, extending, intensifying difference.

The second disjuncture occurs at the level of the subject. Wacquant's most persistent critique charges that Foucault could not account for differentiation in punishment, that Foucault "overlooked both the steep selectivity of penalization and the enduring centrality of punishment to the symbolic projection and material exercise of state power."78 However, punishment is not just aimed at correcting the relation of an individual to an amorphic multiplicity, but to the specific social group; it is precisely a tool of individuation and differentiation. Wacquant has his own set of critics, who criticize his functionalism and unidirectional flow of power from "bureaucratic field" to subject, his reading of the bureaucratic field as a penal actor rather than an effect of governance, his lack of sensitivity to difference across sites, and his reading practices generally. ${ }^{79}$ Complementarily with these critiques, I want to suggest the presence of a real impasse between Wacquant and Foucault at the level of the subject. Wacquant's use of the "bureaucratic field" presupposes strategic agents with interests, goals, desires, and wills. Subjects predicate the field. For Foucault, in fact, none of that is clear; instead, subjects are constituted by power relations as much as they may bring power into play. Subjects cannot be assumed, as Wacquant does. Thereby Foucault can hold that difference is created in prison-punitive power materialized-after it had been extended in a sanction. At one level, the creation and perfection of subjects is an ongoing process in disciplinarity's "perfect continuity of the punitive and the penal." 80 At another level, punitive power operates outside the prison, the penal system, and the state as a matter of its very function.

\footnotetext{
${ }^{77}$ Michel Foucault, "Alternatives to Prison: Dissemination or Decline of Social Control?," Theory, Culture \& Society 26:6 (2009), 24; Punitive Society, 67-68; Michel Foucault, "To Punish Is the Most Difficult Thing There Is" [1981] in Power. Essential Works of Michel Foucault, 1954-1984, Vol. 3, ed. James D. Faubion (2000), 462464.

${ }_{78}$ Wacquant, "Bourdieu, Foucault, and the Penal State in the Neoliberal Era," 125.

${ }^{79}$ David Nelken, “Denouncing the Penal State," Criminology \& Criminal Justice 10:4 (2010), 331-340; Mariana Valverde, "Comment on Loïc Wacquant's 'Theoretical Coda' to Punishing the Poor," Theoretical Criminology 14:1 (2010), 117-120; Stephen J. Collier, "Neoliberalism as Big Leviathan, or ... ? A Response to Wacquant and Hilgers," Social Anthropology 20:2 (2012): 186-195; Mitchell Dean, "Foucault Must Not Be Defended," History and Theory 54:3 (2015), 389-403; cf. Magnus Paulsen Hansen, "Foucault's Flirt? Neoliberalism, the Left and the Welfare State; a Commentary on La Dernière Leçon de Michel Foucault and Critiquer Foucault," Foucault Studies 20 (2015), 302n.64. Nelken notes that Wacquant "can be less than generous in appraising the good faith of academics with whom he disagrees."

80 Punitive Society, 194.
} 


\section{THE PUNITIVE CITY AS TECHNOLOGY AND DIAGRAM}

The $18^{\text {th }}$ century reformers' theories responded to observed limitations internal to sovereign power's capacity to punish. Their proposal-the "punitive city"-was superseded almost immediately by the development of the disciplines. Yet it is worth dwelling on. In this section, I present a dual reading of the "punitive city," first as fantasy-abstraction of the reformers, then as a diagram of power. Positing the punitive city as a diagram deepens the account of how punitive power is exercised at the joins of fragment-individual and individual-multiplicity, and proposes to link punishment and deterrence more robustly. Up to this point I have used Foucault to authorize a reading of Foucault; now I use Foucault to authorize a critique of Foucault, specifically the dichotomy of "punitive city or coercive institution" and the disciplinary replacement of punitive power. Two critiques ground the argument. First, I consider how disciplinarity operates by channeling or appropriating other technologies of power within its institutions, and point to how the punitive city diagram can serve as its exterior condition. Second, I argue that Foucault's preoccupation with bounded spatial assemblages proposes an unnecessary conflict between disciplinary institution and the punitive city, which does not operate as a spatial enclosure. Immediately, however, I describe Foucault's account of the genesis and key features of the punitive city.

The limits that judges and juries placed on the penal sanction taught the reformers several important lessons. One was the necessity of attending to prevailing moral beliefs among those subject to the law and those charged with adjudicating it. They noted that when the law mandated sentences that were too severe or too lenient, judges and magistrates often evaded or deliberately misapplied the law. ${ }^{81}$ A second lesson was the impracticality of combatting the prevalence of a given offence with a drastic increase in the severity of its sanction. Adjudicators had resisted oversevere penalties with behaviors such as "pious perjury," in which they could "avoid applying the penalty by disqualifying the crime" - that is, finding "facts" to undervalue or underdescribe sizes, distances, amounts, or quantities so as not to apply mandated but unjust sentences. ${ }^{82}$ This signaled that disproportionate punishments amplified resistance to the law. A third lesson was the danger inhering in an economy of power that overinvested in local administration. Powers of particularist application created opportunities for subversion and disorder. In response, the reformers sought "to insert the power to punish more deeply into the social body"83 - in other words to eliminate the relays between sovereign command and penalty, to the greatest extent possible. They revised the aim of adjudication, from justice-a particularistic concern-to that of fairness - a general

\footnotetext{
${ }^{81}$ Conflict between the sovereign and the local administration of the law was occasionally more open. In the 24 November 1971 lecture of Théories et institutions pénales, Foucault's notes give an example of local administrators refusing to register a royal edict meant to punish those who participated in a series of local popular uprisings.

82 Punitive Society, 105, 119 n. 14. This concrete example owes its presence in this paper to the excellent editorial apparatus of translator Graham Burchell and editor Bernard Harcourt.

${ }^{83}$ Discipline E Punish, 82.
} 
concern about consistency of procedure. At the same time, the reformers minimized the role of the individual uptake in juridical procedures: what is most important is that the mass of individuals recognize that they are subject to a punitive power, rather than their testifying to its moral legitimacy.

The possibility of power's failure or, worse yet, its diversion led the reformers to propose several disjunct objectives for their technology of power. Foucault terms these "rules." The "rule of minimum quantity" mandates that material "disadvantage" of punishment must exceed the material "advantage" to the crime. Moreover, the representation of the material disadvantage must be sufficient to prevent future offenses. The "rule of sufficient ideality" specifies that punishment must be displayed or known to be preventative, and that it had to be known with an adequate intensity of psychical pain. Conceiving of the punishment had to give "displeasure" per se. Deterrence is formulated in Foucault's "rule of lateral effects": "The penalty must have its most intense effects on those who have not committed the crime." 84 The "rule of perfect certainty" posits that each crime have a clear penalty, that the catalog of crimes be known to all in the form of laws, and that each crime must be punished. What defined each crime would be certain, its penalty would be certain, and it was to be certain that the crime would be penalized. The "rule of common truth" mandates that guilt or innocence be determined only through the idea of proofs and measures of evidence, and that the state banish lingering feudal forms of the test. With this latter pair, the reformers related two problematics: the first, of maximizing the social enforcement of obedience to the law, through the public proclamation of laws-to generate a subjective investment in the law-and the second, of deterrence, which presupposes an epistemological relation between offense and punishment. Finally, the rules must allow for a contingency function, such that "silence of the law must not harbour the hope of impunity" for wrong behavior. ${ }^{85}$ Nor may subjects find impunity within the law, since "the rich do not fear fines nor the notorious infamy." 86 To effectively hold social control, an individualization of the sentence to offender is needed, which Foucault terms the "rule of optimal specification."

The reformers' problematic culminated in the fantasy-abstraction of the punitive city. Foucault allegorizes a nearly unbroken extensity of "hundreds of tiny theaters of punishment":

This, then, is how one must imagine the punitive city. At the crossroads, in the gardens, at the side of roads being repaired or bridges built, in workshops open to all, in the depths of mines that may be visited, will be hundreds of tiny theatres of punishment. Each crime will have its law; each criminal his punishment. It will be a visible punishment, a punishment that tells all, that explains, justifies itself, convicts: placards, different-coloured caps bearing inscriptions, posters, symbols, texts read or printed, tirelessly repeat the code...But the essential point, in all these real or

\footnotetext{
84 Ibid., 95.

85 Ibid., 98.

${ }^{86}$ Ibid.
} 
magnified severities, is that they should all, according to a strict economy, teach a lesson: that each punishment should be a fable. ${ }^{87}$

The punitive city is doubly teleological. At one level, the public display of punishments educates the population, presenting object-lessons that would testify to the consequences of violating the social order. By locating punishments in "hundreds of tiny theatres" across the city, the reformers could shape the urban order through representation and belief. Their punishments would both manifest and testify to "a functioning of penal power, distributed throughout the social space...[and] a power to punish that ran the whole length of the social network." 88 At another level, the punitive city exploits visibility and everyday movement. The "sights" of the punitive city turn as much on their commonality-dependably encountered, mundane, and held in common - as on the viewer's acceptance of the punishment's representational content. That is, the punitive city would expose and habituate its residents to the sights of punishment in order to "initiate" them as subjects through self-recognition and subjective identification.

The representational stakes are indicated by Foucault's summation: punishments are to be "fables." Fables, of course, have morals. Likewise, just as a fable has characteristic structural elements and narrative techniques, the punishments were to "shape the discourse that each individual has with others and by which crime is forbidden to all by all." ${ }^{99}$ In this way, punishment in the punitive city reiterates Foucault's earlier discussion of fable in an essay on Jules Verne..$^{90}$ A fable, he says, has a "content," a form of "public discourse" in how it is recounted, and a "speaking subject." The reformers' analogical system of penalties, in which "each crime will have its law," 91 conforms to the "fabulous" order: "The punishment must proceed from the crime" - the content - "the law must appear to be a necessity of things" - the form of discourse - "and power must act while concealing itself beneath the gentle force of nature" as "speaking subject." 92 Above each recounting, the united author-authority of the punishment remains. However, the punitive city is also a governing ideal, and must attend to its political subjects who comprise an audience. The penalty might falter as punishment if irregular and arbitrary penality establishes not an offense-penalty causal story but rather, at best, a link between the penalty and being caught. Further, the punishment-fable must generate a reflexive understanding on the part of the audience while it sustains authority's position as arbiter of interpretation.

Through sight, movement, and material penalties the punitive city makes appear an asymmetric opposition of authority and individual offender. The punitive city orchestrates visibility. In this way it may be read diagrammatically, relating a set of non-

\footnotetext{
${ }^{87}$ Ibid., 113.

${ }^{88}$ Ibid., 129-130.

${ }^{89}$ Ibid., 110.

${ }_{90}$ Michel Foucault, "Behind the Fable" [1966], in Aesthetics, Method, and Epistemology. Essential Works of Michel Foucault, 1954-84, Vol. 2, ed. James D. Faubion (1998), 137-146.

91 Discipline E Punish, 113.

92 Ibid., 106.
} 
discursive formations to a set of discursive formations. Foucault's most famous diagram, the panopticon, presents "a mechanism of power reduced to its ideal form; its functioning, abstracted from any obstacle, resistance or friction, must be represented as a pure architectural and optical system: it is in fact a figure of political technology that may and must be detached from any specific use." 93 In an echo of Foucault's distinction between "content" and "public discourse," Deleuze describes the panopticon to make a "correspondence" or "coadaptation" between, first, a discursive form of penal law whose content concerns criminals and whose public discourse concerns the purposes and procedures of confinement, and, second, a non-discursive formation with a content of the concrete structure and its "form" and function "to see without being seen." 94 Following Deleuze's analysis of Foucault, the diagram is two irreducible formations that rely upon "a mutual presupposition operating between" them, a novel function immanently caused through the intermingling of incongruous functions. ${ }^{95}$

The punitive-city diagram might be said to map points through which punitive power passes, without determining the use or outcome of that immanent organization. ${ }^{96}$ The punitive city links residents' unwilled "'pain' of the idea of 'pain'" to the forced visibility of offenders ${ }^{97}$; each of these has a correspondence between representational and non-representational elements (an idea of pain to a feeling of "displeasure"; an identification of the scene to one's passing through it). The correspondences might be said to join fragments to individuals as much as, on a different level, the technology of the punitive city joins individuals to multiplicities. As a diagram, the punitive city is closely related to the panopticon: both rely on visibility and representation to, as Deleuze says, "impose a particular conduct on a particular human multiplicity." 98 They correspond in penality, in the "system of language that classifies and translates offences and calculates sentences." 99 But where the multiplicity of discipline "is reduced and confined to a tight space," the punitive city's form utilizes not confinement but motion, not "seeing without being seen" but a dependable experience of "seeing another punished." Deleuze notes that "Form here can have two meanings: it forms or organizes matter; or it forms or finalizes functions and gives them aims," and defines the panoptic diagram's material organization as the prison itself, which restricts movements, and its function as punishment. ${ }^{100}$ In the punitive city, the formal matter is the built environment, allowing for circulations and movements, and the formalized function is deterrence. The punitive city expands rather than segments; it habituates with

\footnotetext{
93 Ibid., 205.

94 Deleuze, Foucault, 32-33, 47ff. The four-part form is Deleuze's appropriation of Louis Hjelmslev's semiotic theory of the sign-function, which uses the terminology "content," "expression," "form," and "substance." Deleuze considers two dyads: content-form/content-substance and expressionform/expression-substance. I thank an anonymous reviewer for making this point.

${ }_{95}^{5}$ Foucault, 33-34; Jakub Zdebik, Deleuze and the Diagram: Aesthetic Threads in Visual Organization (2013).

${ }^{96}$ Cf. Foucault, Discipline $\mathcal{E}$ Punish, 205-206.

${ }_{97}$ Discipline E Punish, 94.

98 Foucault, 34.

99 Ibid., 32.

100 Ibid., 33.
} 
representations rather than instruments of training; it deters with the goal of freezing a social world that is ever-moving. It couches a dream of stasis within itself.

Considering the punitive city as a diagram enables a revision to Foucault's thought. The punitive city and coercive or disciplinary institution may be functionally complementary, spatially non-exclusive, and may mutually articulate in a strategic practice that subordinates individuals and collectivities. This argument is, in a way, a Foucauldian one. In the Security, Territory, Population lectures, Foucault held that the major technologies of power in the Global North-sovereign power, discipline, biopower-form a "solid series"101 rather than a supplantation, a symbiosis rather than succession. If so, their correlative diagrams might also operate in concert. To begin, how do we account for authority in punishment within the disciplinary institution, both in the forms of power that the disciplinary institution wields to make bodies docile, and in that which guarantees the exercise of disciplinary authority? In the "Truth and Juridical Forms" lectures, disciplinary power operates by coupling an economic power-in the form of exchange or production - to a political power-such as the rights to expel, differentiate, or impose rules - and, further, to a judicial power that renders decisions about punishment and reward. ${ }^{102}$ However, the institutional cooptation of nondisciplinary power to operate mechanically within a disciplinary strategy cannot guarantee the institution's continual operation or reproduction. A fully self-contained institution is vulnerable to cooptation or takeover by the very individuals it operates to make docile; as Foucault says in the Punitive Society lectures, "the workshop could not function in the structure of the convent or the barracks if there were not the police or the army alongside." 103 In other words, disciplinary institutions require a form of power exterior to them and yet made to operate within the same function. ${ }^{104}$ At issue, then, is whether and the extent to which the sights of the punitive city could serve as the disciplinary institution's exterior function. This question inverts the reformers' problem: where sovereignty's general discontinuity made it ineffective as a guarantor of the social order within the territory - according to the reformers - the disciplinary institution has effective continuity of power within but only on the condition of a power without.

Foucault offers a spatial juxtaposition between the punitive city and coercive institution. The punitive city is extensive, with punitive power "distributed throughout the social space" by means of spectacle yet within an urban site. By contrast, Foucault says that "the first action of discipline is in fact to circumscribe a space in which its power and the mechanisms of its power will function fully and without limit." 105 The coercive institution segments, confines, and then imposes a conduct. Despite the apparent contrast, both metaphors presuppose a space that is divided, more or less clearly, with a discrete inside juxtaposed to an unformed outside. The tendency to think of spatial relations as the occurrence of discrete objects that have interiors (and

\footnotetext{
101 Security, Territory, Population, 108.

102 “Truth and Juridical Forms," 83; see also Punitive Society, 214-215.

${ }^{103}$ Punitive Society, 209.

104 Foucault, 43.

105 Security, Territory, Population, 45; see also Discipline E Punish, 130-131.
} 
consequently, which might be fractured) and exteriors or limits is typical of Foucault's writing. ${ }^{106}$ The list compiled by the French geographers who interviewed him for the journal Hérodote describes a "profuse use of spatial metaphors - position, displacement, site, field; sometimes geographical metaphors even - territory, domain, soil, horizon, archipelago, geopolitics, region, landscape."107 Similarly, in the 1964 essay "The Language of Space," Foucault gives "the gap, distance, the intermediary, dispersion, fracture and difference" as spatial metaphors. ${ }^{108}$ One sees a preponderance of distancedelineated relations in bounded space. Yet analogizing the reformers' ideal to practices within urban space risks circumscribing the operation of deterrent power to a territorial form. The diagram of the punitive city does not hinge on an architectural form analogous to how "stones can make people docile and knowable"109 in the diagram of the panopticon. Rather, the spatial proposition of the punitive city disperses the sights of punitive power, giving merely the appearance that the punishing authority's power is spatially continuous. In contrast to a sovereign power that attempts and fails to blanket and saturate public space, the spatial model for the power proposed by the reformers is, on the one hand, a temporal irregularity in a regular spatial form, such that its location is constantly varying, like a sound wave or ripples when throwing rocks on a lake; and, on the other hand, described by a shape or topology that never exists except in representation of its predictable effects, such as an orbit or gravity. The use of violence and spectacle in the punitive city does not and cannot displace the coercive institution spatially because they are not mutually exclusive productions of spatial interiority by power and they do not produce space in substantially identical ways.

The problem that the punitive city attempts to solve is a functional equivalence of forces. The reformers were limited by an inability to secure compliance continually and uniformly across space, as biopolitical modes are similarly limited today. The punitive city's orchestration of visibility is meant to deter, to "indefinitely postpone"110 any actual combat between forces on the idea that, as Foucault paraphrases Hobbes, either the stronger would brutally subdue the weaker or "relationship of force would remain virtual, precisely because the weak are timorous."111 My own objective in this section has been to locate the punitive city as a diagram of power, one that might serve as a "tool" or a "'gadget' of approach or methodology." 112 One can both accept some or all of

\footnotetext{
106 In addition to the below, see the terms cited by Peter Johnson, "Foucault's Spatial Combat," Environment and Planning D: Society and Space 26:4 (2008), 612-613; and Jeremy W. Crampton, "Space, Territory, Geography," in A Companion to Foucault, ed. Christopher Falzon, Timothy O'Leary, and Jana Sawicki (2013), 384-399.

${ }_{107}$ Michel Foucault, "Questions on Geography" [1976], in Space, Knowledge, and Power: Foucault and Geography, ed. Jeremy W Crampton and Stuart Elden (2007), 176.

${ }^{108}$ Michel Foucault, "The Language of Space" [1964], in Space, Knowledge, and Power: Foucault and Geography, ed. Jeremy W Crampton and Stuart Elden (2007), 163.

${ }_{109}$ Discipline \& Punish, 172.

110 William Bogard, "Discipline and Deterrence: Rethinking Foucault on the Question of Power in Contemporary Society," The Social Science Journal 28:3 (1991), 341.

111 Society Must Be Defended, 91.

112 "Questions on Geography," 174.
} 
Foucault's various claims about the transition to "disciplinary society" while contesting Foucault's claim about the replacement of the punitive city by coercive institution. In a sovereign system, the punitive-city function gives the appearance of the sovereign will across space; in discipline, it models both an external deterrence against revolution within the workshop and an internal deterrence that would establish an individual's obedience to the rules of the school, factory, or prison. Such deterrence is the recourse for, as William Bogard writes, a paradoxical "inability to exercise power," perhaps a tacit admission of authority's weakness. ${ }^{113}$

\section{CONCLUSION: PUNISHMENT, DISCIPLINE, AND THE DIAGRAM OF DETERRENCE}

Foucault's account of the punitive city and disciplinary institution as competing models invites a final reflection. Foucault's claim the "the other side of the disciplinary relationship is punishment"114 invites at least four readings on the relationship of discipline and punishment. Discipline and punishment might comprise a single, doublesided technology, as suggested by Foucault's claim of sovereign punishment as a "corrective and disciplinary technique."115 Alternatively, discipline and punishment might be necessarily complementary yet distinct. In yet another reading, discipline might inscribe punishment within itself, either as a technology or as a historical formation. I find this the strongest reading, and it has been that which I have used throughout this paper. But in a final reading, discipline and punishment might operate on the basis of a "mutual presupposition." If "discipline is a mode of individualization of multiplicities,"116 and if disciplinary power requires each of the elements of punitive power to operate-authority, bodies, individual-collective and fragment-individual joins, and a causal story - then punitive power might condition disciplinary power's field of intelligibility. The open question is whether disciplinary tactics are necessarily punitive or instead if disciplinary power rearranges the elements of punishment. I leave this question for future scholarship. But should punishment make discipline make sense, it would offer inroads to a second question, of the relation between punitive and disciplinary power considering Foucault's unsaid but prepared remark regarding "the analysis of a form of power I have called punitive, which it would be better to call disciplinary."117

This paper has provided a minimal account of an analytics of punishment immanent in Foucault's work. As an "analyzer of power," punishment focalizes the power relations through which punitive practices and procedures arise, such as "pious multiplicity" of the early monastics and the sovereign economy of the body. As a

\footnotetext{
113 Bogard, "Discipline and Deterrence," 340.

114 Psychiatric Power, 51.

115 Security, Territory, Population, 7.

116 Ibid., Security, Territory, Population, 12.

117 Punitive Society, $237 \mathrm{n}$.
} 
technology, punitive power seizes the body in the name of an authority or reified power, targeting the fragment-individual and individual-multiplicity joins, to subordinate individuals and/or multiplicities. As a diagram, the punitive city maps the use of punitive power to order the social, as well as the limitations in so doing. Readings of the spectacle, especially Debordian readings, generally present representation as a domain of state strength. My analysis here, particularly of the punitive-city diagram, would suggest that the state makes recourse to representation when it perceives that power differentials are not sufficiently extreme, when it cannot compel compliance to its will. This should not, however, imply an absence of power, but rather a deficit of the coordination necessary for sovereign governance.

The $18^{\text {th }}$ century reformers 118 influence may be traced in contemporary practices that include neoliberal penality, via "broken windows" policing and cost-benefit legal analyses ${ }^{119}$; migration governance that attempts to deter migration to the global north by increasing mortality ${ }^{120}$; and in the pervasive practice to identify subgroups as prone to wrong-doing, such as racialized tropes of criminality. ${ }^{121}$ Foucault repeatedly emphasizes that the reformers were targeting the working class, not their own bourgeois peers and certainly not all equally. ${ }^{122}$ He critiqued the punitive city as limited in use and reach, relying too much on the power of representation for its purposes. Yet if the punitive city serves as a diagram of deterrent power, then its activation might be widespread. Neoliberal penality, migration deterrence, and racialized criminality all employ a directed punitive power that blurs the distinction between innocent and "potentially guilty" 123 and reinscribes subgroup difference. Foucault had imagined that the semiotic operation of punishment would be effective for subordination when crime faithfully implied punishment. This is not the only possibility. A different semiotic couple may take hold, as in the US, where blacks and whites use drugs at the same rates, and where whites are more likely to sell drugs, yet blacks are more likely to be arrested for drug offenses and more likely to be sent to prison when they are. ${ }^{124}$ The political rationality is that prisoners are incarcerated not because of selective effects but because of their legal guilt. This system is stable. It also indicates something about punishment and the punitive-city diagram: that the semiotics of punishment afford a political use when their

\footnotetext{
118 Birth of Biopolitics, 248ff.; Andrew Dilts, "Foucault Meets Gary Becker: Criminology beyond Discipline and Punish," in Discipline, Security, and beyond: Rethinking Foucault's 1978 \& 1979 Collège de France Lectures, ed. Bernard E. Harcourt (2008), 77-100; Bernard E. Harcourt, "Neoliberal Penality: A Brief Genealogy," Theoretical Criminology 14:1 (2010), 74-92.

119 Dilts, "Foucault Meets Gary Becker"; Harcourt, "The '73 Graft."

${ }^{120}$ Vicki Squire, "Governing Migration through Death in Europe and the US: Identification, Burial and the Crisis of Modern Humanism," European Journal of International Relations 23:3 (2017), 513-532.

${ }_{121}$ Natalie Cisneros, “Resisting 'Massive Elimination': Foucault, Immigration, and the GIP," in Active Intolerance, ed. Perry Zurn and Andrew Dilts (2016), 241-257.

122 e.g. Discipline E Punish, 276.

${ }^{123}$ Discipline \& Punish, 108.

124 E.g. Ojmarrh Mitchell and Michael S. Caudy, “Examining Racial Disparities in Drug Arrests," Justice Quarterly 32:2, 288-313.
} 
"direction" is reversed, if a prisoner - and particularly a minoritized prisoner faithfully implies a crime. ${ }^{125}$

\section{References}

Alford, C. Fred, "What Would It Matter If Everything Foucault Said about Prison Were Wrong? Discipline and Punish after Twenty Years," Theory and Society 29:1 (2000), 125-146. https://doi.org/10.1023/A:1007014831641.

Bogard, William, "Discipline and Deterrence: Rethinking Foucault on the Question of Power in Contemporary Society," The Social Science Journal 28:3 (1991): 325-346. https://doi.org/10.1016/0362-3319(91)90017-X.

Chantraine, Gilles, "The Post-Disciplinary Prison," in Discipline, Security, and beyond: Rethinking Foucault's 1978 \& 1979 College de France Lectures, ed. Bernard E. Harcourt, 55-76. Carceral Notebooks: Chicago, 2008.

Cisneros, Natalie, “Resisting 'massive Elimination': Foucault, Immigration, and the GIP," in Active Intolerance, ed. Perry Zurn and Andrew Dilts, 241-257. New York: Palgrave Macmillan, 2016. https://doi.org/10.1057/9781137510679_17.

Collier, Stephen J., "Neoliberalism as Big Leviathan, or ... ? A Response to Wacquant and Hilgers," Social Anthropology 20:2 (2012), 186-95. https://doi.org/10.1111/j.14698676.2012.00195.x.

Crampton, Jeremy W., "Space, Territory, Geography," in A Companion to Foucault, ed. Christopher Falzon, Timothy O'Leary, and Jana Sawicki (2013), 384-399. Malden MA and Oxford: Wiley-Blackwell, 2013. https://doi.org/10.1002/9781118324905.ch19.

Davis, Angela Y., "Racialized Punishment and Prison Abolition," in The Angela Y. Davis Reader, ed. Joy James, 96-107. Malden, MA: Blackwell, 1998.

Dean, Mitchell, Critical and Effective Histories: Foucault's Methods and Historical Sociology. New York: Routledge, 2002.

Dean, Mitchell, "Foucault Must Not Be Defended." History and Theory 54:3 (2015), 389403. https://doi.org/10.1111/hith.10767.

Deleuze, Gilles, Foucault. London and New York: Continuum, 1999.

Dilts, Andrew, "Foucault Meets Gary Becker: Criminology beyond Discipline and Punish," in Discipline, Security, and beyond: Rethinking Foucault's 1978 \& 1979 Collège de France Lectures, ed. Bernard E. Harcourt, 77-100. Carceral Notebooks: Chicago, 2008.

Dreyfus, Hubert L. and Paul Rabinow, Michel Foucault: Beyond Structuralism and Hermeneutics. Chicago: University of Chicago Press, 1983.

Foucault, Michel, Abnormal: Lectures at the Collège de France 1974-1975. Ed. Valerio Marchetti and Antonella Salomoni. London: Verso, 2003.

Foucault, Michel, §Alternatives to Prison: Dissemination or Decline of Social Control?" [1993]. Theory, Culture \& Society 26:6 (2009), 12-24.

Foucault, Michel, "Behind the Fable" [1966] in Aesthetics, Method, and Epistemology. Essential Works of Michel Foucault, 1954-84, Vol. 2, ed. James D. Faubion, 137-46. New York: The New Press, 1998.

\footnotetext{
${ }^{125}$ Angela Y Davis, "Racialized Punishment and Prison Abolition," in The Angela Y. Davis Reader, ed. Joy James (1998), 96-107.
} 
Foucault, Michel, Discipline and Punish: The Birth of the Prison [1975]. New York: Vintage, 1979.

Foucault, Michel, Lectures on the Will to Know: Lectures at the Collège de France (1970-1971). Basingstoke: Palgrave Macmillan, 2009.

Foucault, Michel, "Nietzsche, Genealogy, History" [1971] in Aesthetics, Method, and Epistemology. Essential Works of Michel Foucault, 1954-84, Vol. 2, ed. James D. Faubion, 369-391. New York: The New Press, 1998.

Foucault, Michel, Psychiatric Power: Lectures at the Collège de France, 1973-74. Ed. Jacques Lagrange. New York: Palgrave Macmillan, 2006.

Foucault, Michel, "Questions on Geography" [1976] in Space, Knowledge, and Power: Foucault and Geography, ed. Jeremy W Crampton and Stuart Elden, 173-182. London and New York: Routledge, 2007.

Foucault, Michel, Security, Territory, Population: Lectures at the Collège de France 1977-78. Basingstoke, UK: Palgrave Macmillan, 2009.

Foucault, Michel, "Society Must Be Defended": Lectures at the Collège de France, 1975-76. Ed. Mauro Bertani and Alessandro Fontana. New York: Picador, 2003

Foucault, Michel, The Birth of Biopolitics: Lectures at the Collège de France, 1978-1979. Ed. Michel Senellart. Basingstoke, UK and New York: Palgrave Macmillan, 2008

Foucault, Michel, “The Language of Space" [1964], in Space, Knowledge, and Power: Foucault and Geography, ed. Jeremy W. Crampton and Stuart Elden, 163-167. London and New York: Routledge, 2007.

Foucault, Michel, The Punitive Society: Lectures at the College de France 1972-1973. Ed. Bernard E. Harcourt. New York: Palgrave Macmillan, 2015.

Foucault, Michel, Théories et institutions pénales: Cours au Collège de France (1971-1972). Ed. Bernard E Harcourt. Paris: Éditions du Seuil/Gallimard, 2015.

Foucault, Michel, "To Punish Is the Most Difficult Thing There Is" [1981], in Power. Essential Works of Michel Foucault, 1954-1984, Vol. 3, ed. by James D. Faubion, 462-464. New York: The New Press, 2000.

Foucault, Michel, “Truth and Juridical Forms" [1973], in Power. Essential Works of Michel Foucault, 1954-1984, Vol. 3, ed. James D. Faubion, 1-89. New York: The New Press, 2000.

Foucault, Michel, Wrong-Doing, Truth-Telling: The Function of Avowal in Justice. Ed. Fabienne Brion and Bernard E. Harcourt. Chicago and London: University of Chicago Press, 2014.

Gamez, Patrick, “Did Foucault Do Ethics? The 'Ethical Turn,' Neoliberalism, and the Problem of Truth," Journal of French and Francophone Philosophy - Revue de la philosophie française et de langue française XXVI:1 (2018): 107-133. https://doi.org/10.5195/jffp.2018.818.

Garland, David, "Frameworks of Inquiry in the Sociology of Punishment," The British Journal of Sociology 41:1 (1990), 1-15.

Garland, David, Punishment and Modern Society: A Study in Social Theory. Chicago: University of Chicago Press, 1990.

Genosko, Gary, "Special Semiotic Characters: What Is an Obstacle-Sign?" MediaTropes IV:1 (2013), 101-111. 
Gros, Frédéric, "Is There a Biopolitical Subject? Foucault and the Birth of Biopolitics," in Biopower: Foucault and Beyond, ed. Vernon Cisney and Nicolae Morar, 259-273. Chicago: University of Chicago Press, 2016.

Hansen, Magnus Paulsen, "Foucault's Flirt? Neoliberalism, the Left and the Welfare State; a Commentary on La Dernière Leçon de Michel Foucault and Critiquer Foucault," Foucault Studies 20 (2015): 291-306.

Harcourt, Bernard E, “Neoliberal Penality: A Brief Genealogy," Theoretical Criminology 14:1 (2010): 74-92.

Harcourt, Bernard E., The '73 Graft: Punishment, Political Economy, and the Genealogy of Morals." Columbia Public Law Research Paper. Columbia University, 2015. ssrn.com/abstract=2673062.

Jessop, Bob, "From Micro-Powers to Governmentality: Foucault's Work on Statehood, State Formation, Statecraft, and State Power," Political Geography 27 (2006), 34-40.

Johnson, Peter, "Foucault's Spatial Combat," Environment and Planning D: Society and Space 26:4 (2008), 611-26. https://doi.org/10.1068/d3007.

Lloyd, Henry Martyn, "Power, Resistance, and the Foucauldian Technologies," Philosophy Today 56:1 (2012), 26-38.

Mitchell, Ojmarrh and Michael S. Caudy, "Examining Racial Disparities in Drug $\begin{array}{lllll}\text { Arrests," } & \text { Justice } & \text { Quarterly } & \text { 288-313. }\end{array}$ https://doi.org/10.1080/07418825.2012.761721

Nelken, David, "Denouncing the Penal State," Criminology \& Criminal Justice 10:4 (2010), 331-340. https://doi.org/10.1177/1748895810382382.

Newheiser, David, "Foucault, Gary Becker and the Critique of Neoliberalism," Theory, Culture \& Society 33:5 (2016), 3-21. https://doi.org/10.1177/0263276415619997.

Nietzsche, Friedrich. On the Genealogy of Morality [1887]. Cambridge: Cambridge University Press, 2006.

Paras, Eric, Foucault 2.0: Beyond Power and Knowledge. New York: Other Press, 2006

Patton, Paul, "Power and Biopower in Foucault," in Biopower: Foucault and Beyond, ed. Vernon Cisney and Nicolae Morar, 102-117. Chicago: University of Chicago Press, 2016.

Squire, Vicki, "Governing Migration through Death in Europe and the US: Identification, Burial and the Crisis of Modern Humanism," European Journal of International Relations 23:3 (2017), 513-532. https://doi.org/10.1177/1354066116668662.

Taylor, Chloë, “Foucault and Familial Power," Hypatia 27:1 (2012): 201-218. https://doi.org/10.1111/j.1527-2001.2011.01171.x.

Valverde, Mariana, “Comment on Loïc Wacquant's 'Theoretical Coda' to Punishing the Poor," Theoretical Criminology 14:1 (2010), 117-120.

Wacquant, Loïc, "Bourdieu, Foucault, and the Penal State in the Neoliberal Era," in Foucault and Neoliberalism, ed. Daniel Zamora and Michael C Behrent, 114-133. Malden, MA: Polity Press, 2016.

Wacquant, Loïc, Punishing the Poor: The Neoliberal Government of Social Insecurity. Durham, NC: Duke University Press, 2009. 
Zdebik, Jakub. Deleuze and the Diagram: Aesthetic Threads in Visual Organization. London and New York: Continuum, 2013.

Author info

Mario Bruzzone

Department of Geography

University of Wisconsin - Madison

USA

email: bruzzone@wisc.edu

Mario Bruzzone holds a PhD in Geography from the University of Wisconsin - Madison. His scholarship has appeared in Antipode, Cultural Geographies, Political Geography, and Urban Geography, among others. His current project theorizes the US-Mexico border regime through Foucauldian punitive power. 